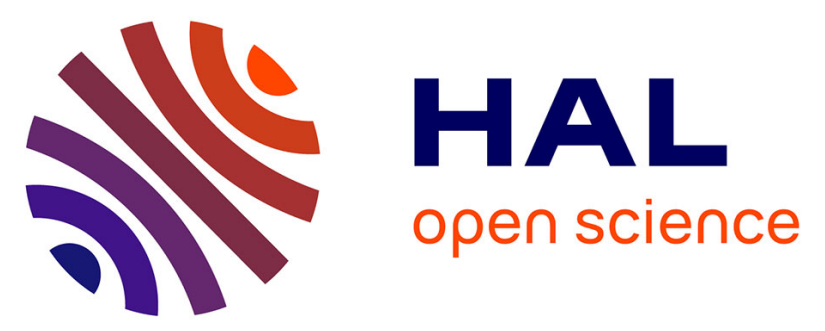

\title{
A novel point mutation within the juxtamembrane domain of the gene in acute myeloid leukemia
}

Valentina Gianfelici, Daniela Diverio, Massimo Breccia, Sonia Buffolino, Valentina Derme, Attilio Lascio, Marilisa Marinelli, Simona Santangelo, Giovanna Meloni, Robin Foà

\section{To cite this version:}

Valentina Gianfelici, Daniela Diverio, Massimo Breccia, Sonia Buffolino, Valentina Derme, et al.. A novel point mutation within the juxtamembrane domain of the gene in acute myeloid leukemia. Annals of Hematology, 2010, 90 (7), pp.845-846. 10.1007/s00277-010-1092-0 . hal-00615405

\section{HAL Id: hal-00615405 https://hal.science/hal-00615405}

Submitted on 19 Aug 2011

HAL is a multi-disciplinary open access archive for the deposit and dissemination of scientific research documents, whether they are published or not. The documents may come from teaching and research institutions in France or abroad, or from public or private research centers.
L'archive ouverte pluridisciplinaire HAL, est destinée au dépôt et à la diffusion de documents scientifiques de niveau recherche, publiés ou non, émanant des établissements d'enseignement et de recherche français ou étrangers, des laboratoires publics ou privés. 


\section{A NOVEL POINT MUTATION WITHIN THE JUXTAMEMBRANE DOMAIN OF THE FLT3 GENE IN ACUTE MYELOID LEUKEMIA}

Valentina Gianfelici (1), Daniela Diverio (1), Massimo Breccia (1), Sonia Buffolino (1), Valentina Derme (1), Attilio Di Lascio (1), Marilisa Marinelli (1), Simona Santangelo (1), Giovanna Meloni (1) and Robin Foà (1)

Affiliation: (1) Division of Hematology, Department of Cellular Biotechnologies and Hematology, "Sapienza" University of Rome, Via Benevento 6, 00161 Rome, Italy.

Corresponding Author: Valentina Gianfelici

Division of Hematology, Department of Cellular Biotechnologies and Hematology, "Sapienza" University of Rome, Via Benevento 6, 00161 Rome, Italy.

e-mail: gianfelici@bce.uniroma1.it

Mobile phone: 0039-3403545378

Keywords: FLT3, point mutations, acute myeloid leukemia 


\section{A NOVEL POINT MUTATION WITHIN THE JUXTAMEMBRANE DOMAIN OF THE FLT3 GENE IN ACUTE MYELOID LEUKEMIA}

Valentina Gianfelici, Daniela Diverio, Massimo Breccia, Sonia Buffolino, Valentina Derme, Attilio Di Lascio, Marilisa Marinelli, Simona Santangelo, Giovanna Meloni and Robin Foà

Division of Hematology, Department of Cellular Biotechnologies and Hematology, "Sapienza" University of Rome, Via Benevento 6, 00161 Rome, Italy.

\section{Dear Editor,}

In acute myeloid leukemia (AML), mutations of the FMS-like tyrosine kinase-3 (FLT3) are found in about one third of patients. The most common mutations are the internal tandem duplication (FLT3ITD) within exon 14 coding the juxta-membrane domain (JM) and the point mutations involving exon 20 coding the second tyrosine-kinase domain (FLT3-TKD). Recently, a third class of activating point mutations in the JM (FLT3-JM-PM) has been identified in AML patients, but its biological and clinical significance remains to be clarified [1].

We hereby described a new mutation within exon 14 of FLT3 and its clinical features.

A 78-year old man presented at our Institute because of fatigue, dyspnoea and fever. The clinical examination showed an axillary lymph node enlargement, while spleen and liver were within the normal limits. Laboratory examination revealed hyperleukocytosis (180 x 10 (9) /L) and the peripheral blood smear showed approximately $98 \%$ of circulating blast cells. A diagnosis of AML was made. The karyotype was: 47,XY,t(9;11)(p22;q23),+8. Sequencing of the NPM1 gene showed a wild-type conformation.

We performed a retrotranscription multiplex polymerase chain reaction (RT-PCR) of both exons 14 and 20 of the FLT3 gene and digestion with the ECO RV enzyme was used to discover the FLT3-TKD, as previously described [2]. The PCR products were run onto a 3\% agarose gel and visualized under UV light. Unexpectedly, after EcoRV digestion the band corresponding to the amplification of the exon 14 was split into two additional abnormal fragments of $292 \mathrm{bp}$ and $74 \mathrm{bp}$, rather than the expected wild type fragment. Moreover, the digestion of the exon 20 product resulted in two bands, as expected in the wild type configuration. Bidirectional sequencing analysis of exon 14 showed a missense mutation in heterozygosis (c.1780 T>A; p.F594I; ENST00000241453).

This work reports a new mutation that inserts a new cleavage site recognized by EcoRV.

As shown in table 1, few cases of FLT3-JM-PMs have been reported in the literature so their clinical significance remains to be clarified [1, 3-5].

The FLT3-JM-PMs are able to transform hematopoietic cells and show constitutive autophosphorylation. Interestingly, treatment with specific FLT3 inhibitors is able to block IL3indipendent proliferation and reduces phosphorylation of STAT5 [1].

This experience raises interesting questions. First, while the adverse clinical impact of FLT3-ITD in adult AML is well established, there is no prognostic study on patients carrying FLT3-JM-PM. Second, the indication that patients carrying these mutations might respond to treatment with selective FLT3 inhibitors underline the importance of analyzing FLT3-JM-PM in AML patients. Since PCR/agarose screening normally does not detect small mutations, additional investigations should be performed. We think that Denaturing High Performance Liquid Chromatography (DHPLC) assay is very sensitive for detection of DNA sequence variation and we recommend this application for large-scale mutation screening. 
Remark, our patient harbored a $\mathrm{t}(9 ; 11)(\mathrm{p} 22 ; \mathrm{q} 23)$. Given that leukemias bearing translocations involving $M L L$ demonstrate high level expression and frequent mutation of FLT3, we hypothesized that $M L L$ fusion proteins and constitutively active FLT3 are cooperating genetic events in the multistep pathogenesis of leukemias [6].

Further studies are necessary to examine the oncogenic role in the pathogenesis of AML and the clinical outcome of patients harboring FLT3-JM-PMs.

\section{References:}

1. Reindl C, Bagrintseva K, Vempati S, Schnittger S, Ellwart JW, Wenig K, Hopfner KP, Hiddemann W, Spiekermann K (2006). Point mutations in the juxtamembrane domain of FLT3 define a new class of activating mutations in AML. Blood 107(9):3700-7.

2. Noguera NI, Breccia M, Divona M, Diverio D, Costa V, De Santis S, Avvisati G, Pinazzi MB, Petti MC, Mandelli F, Lo Coco F (2002). Alterations of the FLT3 gene in acute promyelocytic leukemia: association with diagnostic characteristics and analysis of clinical outcome in patients treated with the Italian AIDA protocol. Leukemia 16:2185-2189.

3. Stirewalt DL, Meshinchi S, Kussick SJ, Sheets KM, Pogosova-Agadjanyan E, Willman CL, Radich JP (2004). Novel FLT3 point mutations within exon 14 found in patients with acute myeloid leukaemia. Br J Haematol. 124(4):481-4.

4. Syampurnawati M, Tatsumi E, Furuta K, Hayashi Y (2007). Four novel point mutations in exons 12, 13, and 14 of the FLT3 gene. Leukemia Research 31(6):877.

5. Stam RW, den Boer ML, Schneider P, Meier M, Beverloo HP, Pieters R (2007). D-HPLC analysis of the entire FLT3 gene in MLL rearranged and hyperdiploid acute lymphoblastic leukemia. Haematologica 92(11):1565-8.

6. Stubbs MC, Kim YM, Krivtsov AV, Wright RD, Feng Z, Agarwal J, Kung AL, Armstrong SA (2008). MLL-AF9 and FLT3 cooperation in acute myelogeneous leukemia: development of a model for rapid therapeutic assessment. Leukemia 22(1): 66-77. 
Table 1. FLT3 JM-PMs described in literature

\begin{tabular}{|c|c|c|c|c|c|c|}
\hline Mutations & Methods & Frequency & Diagnosis & $\begin{array}{c}\text { Cytogenetic/molecular } \\
\text { data }\end{array}$ & $\begin{array}{l}\text { Clinical } \\
\text { Results }\end{array}$ & References \\
\hline Y591C & LightCycler & $1 / 785$ & AML & NA & NA & $\begin{array}{c}\text { Reindl C et al } \\
{[1]}\end{array}$ \\
\hline F594L & LightCycler & $2 / 785$ & AML & NA & NA & \\
\hline F590GY591D & PCR/SSCPs & $1 / 140$ & AML & NA & NA & $\begin{array}{c}\text { Stirewalt DL et } \\
\text { al [3] }\end{array}$ \\
\hline V579A & PCR/SSCPs & $1 / 140$ & AML & NA & NA & \\
\hline V592A & PCR/SSCPs & $1 / 140$ & AML & NA & NA & \\
\hline S574G & Sequencing & $1 / 15$ & AML M2 & FLT3/ITD & NA & $\begin{array}{c}\text { Syampurnawati } \\
\text { M et al [4] }\end{array}$ \\
\hline E598G & Sequencing & $1 / 15$ & AML M2 & FLT3/ITD & NA & \\
\hline K567I & DHPLC & $1 / 30$ & ALL & hyperdiploid & NA & $\begin{array}{c}\text { Stam RW et al } \\
{[5]^{*}}\end{array}$ \\
\hline V579Q & DHPLC & $1 / 30$ & ALL & hyperdiploid & NA & \\
\hline 7 aa insertion at D586 & DHPLC & $1 / 30$ & ALL & hyperdiploid & NA & \\
\hline F594I & $\begin{array}{l}\text { ECO RV } \\
\text { Digestion }\end{array}$ & NA & AML M5 & $\mathrm{t}(9 ; 11)(\mathrm{p} 22 ; \mathrm{q} 23),+8$ & $\begin{array}{c}\text { Death } \\
\text { before } \\
\text { induction }\end{array}$ & $\begin{array}{c}\text { The present } \\
\text { case }\end{array}$ \\
\hline
\end{tabular}

SSCPs: single-stranded conformational polymorphism analyses; NA: not available; ALL: acute lymphoblastic leukemia *study on 30 childhood hyperdiploid ALL patients 